\title{
Analisis Perlakuan Akuntansi Aset Tetap Menurut PSAK No.16 (Revisi 2011) di RSU Pancaran Kasih Manado
}

\author{
Oleh: \\ Paulina Amanda Sadondang ${ }^{1}$ \\ Jullie J Sondakh ${ }^{2}$ \\ Novi Swandari Budiarso ${ }^{3}$
}

\author{
Fakultas Ekonomi dan Bisnis Pendidikan Profesi Akuntansi \\ Universitas Sam Ratulangi Manado \\ Email: novi_sbudiarso@yahoo.com
}

\section{PENDAHULUAN}

Dewasa ini, pelaksanaan pembangunan di berbagai sektor meningkat semakin pesat. Baik di sektor pemerintahan maupun swasta semakin berlomba-lomba untuk meningkatkan tingkat produktivitas dan kualitas pelayanan bagi konsumen atau masyarakat. Pada dasarnya, perusahaan akan melakukan berbagai inovasi untuk mencapai tujuan operasional perusahaan, yaitu memaksimalkan profit dengan cara menjual barang atau jasa kepada pelanggan. Disamping itu, ada juga jenis perusahaan yang memang dalam kegiatan usahanya lebih memprioritaskan pelayanan secara maksimal kepada masyarakat. Jenis organisasi tersebut dikenal dengan organisasi nir-laba (non profit) seperti yayasan (rumah sakit, sekolah, perguruan tinggi) dan badan atau instansi pemerintah.

Perusahaan swasta maupun instansi pemerintah secara tidak langsung dituntut mengikuti perkembangan ilmu pengetahuan dan teknologi saat ini untuk mempertahankan kelangsungan hidup usahanya. Dalam suatu perusahaan atau instansi pasti memiliki berbagai sumber daya yang bisa dimanfaatkan dan dianggap mampu untuk menopang, melanjutkan dan mempertahankan kelangsungan hidup usaha itu sendiri. Dari sekian banyak sumber daya ekonomi yang bisa dimanfaatkan, aset merupakan salah satu yang memiliki peran penting bagi perusahaan.

Aset dimiliki dan digunakan perusahaan untuk kelancaran kegiatan operasional perusahaan, antara lain kas, piutang usaha, persediaan, perlengkapan, asuransi, sewa, peralatan, tanah, bangunan, kendaraan, dan aset lainnya. Semua aset tersebut digolongkan ke dalam dua kelompok, yaitu aset lancar (current assets) dan aset tidak lancar atau aset tetap (fixed assets).

Aset tetap memiliki peranan penting dalam menopang jalannya kegiatan operasional di Rumah Sakit Umum (RSU) Pancaran Kasih Manado. RSU Pancaran Kasih Manado merupakan suatu instansi milik yayasan Medika Gereja Masehi Injili di Minahasa (GMIM) yang menyediakan pelayanan jasa dalam bentuk sarana dan prasarana kesehatan bagi masyarakat. Sebagai penyedia jasa pelayanan kesehatan, tentunya RSU Pancaran Kasih Manado memiliki aset tetap dalam jumlah yang besar, misalnya tanah yang digunakan untuk mendirikan bangunan rumah sakit, gedung rumah sakit yang digunakan untuk pelayanan kesehatan masyarakat, seperti Instalasi Gawat Darurat (IGD), ruangan rawat inap, apotek, ruang administrasi, dan ruangan lain untuk menunjang kinerja pelayanan rumah sakit, kendaraan untuk kegiatan operasional rumah sakit seperti Ambulance yang digunakan untuk membawa orang sakit (dalam keadaan darurat) maupun orang yang meninggal, peralatan-peralatan medis maupun non medis lainnya yang digunakan dalam aktivitas operasional RSU Pancaran Kasih, seperti komputer, meja, kursi, tempat tidur, kursi roda, alat / mesin untuk pemeriksaan, dll.

Pentingnya peranan aset tetap dalam menunjang aktivitas operasional pelayanan RSU Pancaran Kasih Manado bisa dilihat dari total penggunaan aset tetap berdasarkan data laporan keuangan neraca pada tahun 2010 adalah

Rp. 24,582,362,740 dari total keseluruhan aset perusahaan Rp. 25,238,585,990.81 atau $\pm 97 \%$ dari total keseluruhan aset 
perusahaan. Ditinjau dari nilainya ini, perolehan aset tetap memerlukan investasi yang signifikan, manajemen aset yang baik, dan penerapan prosedural yang handal sesuai dengan ketentuan PSAK No.16 yang mengatur tentang pelakuan akuntansi terhadap aset tetap mulai dari pengakuan, pengeluaran setelah pengakuan, pengukuran, penyusutan, penghentian dan pelepasan, serta penyajian dan pengungkapan aset tetap dalam pelaporan keuangan. Namun, terkait dengan kondisi perusahaan yang baru mulai merangkak naik dan kembali melaksanakan kegiatan operasional setelah mengalami kegagalan manajemen beberapa tahun sebelumnya, perusahaan membutuhkan pengaturan dan penanganan yang tepat khususnya untuk penerapan perlakuan akuntansi terhadap aset tetap yang memiliki peran penting bagi kelancaran kegiatan operasional perusahaan, seperti PSAK No.16 (revisi 2011).

Berdasarkan latar belakang yang diuraikan sebelumnya, aset tetap memiliki peranan penting dalam kegiatan operasional dan pengembangan suatu perusahaan. Melihat peranan penting tersebut, maka perumusan masalah yang diangkat dalam penelitian ini adalah: "Bagaimana perlakuan akuntansi terhadap pengakuan, pengeluaran setelah pengakuan, pengukuran, penyusutan, pelepasan, dan pengungkapan aset tetap di RSU Pancaran Kasih Manado sesuai dengan ketentuan PSAK No. 16 (Revisi 2011)?"

Berdasarkan rumusan masalah yang ada maka tujuan yang ingin dicapai dari penelitian ini adalah untuk mengetahui perlakuan akuntansi saat pengakuan, pengeluaran setelah pengakuan, pengukuran, penyusutan, pelepasan, dan pengungkapan aset tetap di RSU Pancaran Kasih Manado dan membandingkannya dengan ketentuan PSAK No.16 (Revisi 2011).

\section{TINJAUAN PUSTAKA}

Akuntansi merupakan salah satu komponen yang memiliki peranan penting bagi perusahaan. Menurut Riahi,Ahmed dan Belkaoui (2011 : 54), Peranan dari akuntansi adalah untuk memberikan informasi mengenai perilaku ekonomi yang diakibatkan oleh aktivitasaktivitas perusahaan dalam lingkungannya.

Aset tetap adalah aset yang bersifat jangka panjang atau secara relatif memiliki sifat permanen serta dapat digunakan dalam jangka panjang (Reeve, dkk. $2010: 2$ ). Menurut Libby.R, dkk (2007 : 395), Aset tetap adalah sumber daya berwujud dan tidak berwujud yang dimiliki perusahaan dan digunakan dalam operasi selama beberapa tahun. Sedangkan menurut PSAK No.16 (Revisi 2011), Aset tetap adalah aset berwujud yang:

(a) dimiliki untuk digunakan dalam produksi atau penyediaan barang atau jasa untuk direntalkan kepada pihak lain, atau untuk tujuan administratif; dan

(b) diharapkan untuk digunakan selama lebih dari satu periode.

Juan dan Wahyuni (2013 : 340) menyatakan bahwa, agar dapat diklasifikasikan sebagai aset tetap, suatu aset harus memiliki karakteristik berikut:

- Aset tersebut digunakan dalam operasi. Hanya aset yang digunakan dalam operasi normal perusahaan saja yang dapat diklasifikasikan sebagai aset tetap.

- Aset tersebut memiliki masa (umur) manfaat yang panjang. Lebih dari satu periode.

- Aset tersebut memiliki substansi fisik. Aset tetap memiliki ciri substansi fisik kasat mata sehingga dibedakan dari aset tak berwujud seperti hak paten dan merk dagang.

Hery (2013 : 267) menyatakan, Harga Perolehan Aktiva tetap meliputi seluruh jumlah yang dikeluarkan untuk mendapatkan aset tersebut. Aktiva tetap akan dilaporkan dalam neraca tidak hanya sebesar harga belinya saja, tetapi juga termasuk seluruh biaya yang dikeluarkan sampai aktiva tersebut siap untuk dipakai.

PSAK No.16 (revisi 2011) mengatur tentang perlakuan akuntansi terhadap aset tetap mulai dari pengakuan, pengeluaran setelah pengakuan, pengukuran, penyusutan, penghentian dan pelepasan, serta penyajian dan pengungkapan aset tetap dalam pelaporan keuangan. 


\section{METODE PENELITIAN}

\subsection{Data}

Penelitian ini merupakan penelitian deskriptif dimana proses analisis deskriptif dalam penelitian ini dilakukan terhadap perlakuan Akuntansi aset tetap berdasarkan ketentuan PSAK No.16 (Revisi 2011) pada RSU Pancaran Kasih Manado. Waktu penelitian dilakukan selama kurang lebih dua bulan yaitu bulan Januari-Februari 2015.

Prosedur penelitian yang digunakan adalah sebagai berikut :

1. Mengamati dan mengumpulkan semua data aset tetap yang dimiliki RSU Pancaran Kasih Manado, melalui proses dokumentasi dalam bentuk laporan keuangan dan daftar aset tetap.

2. Wawancara dengan pihak terkait untuk mengumpulkan informasi tentang perlakuan akuntansi terhadap pengakuan, pengukuran, penyusutan, penghapusan dan pelepasan, serta penyajian dan pengungkapan aset tetap di RSU Pancaran Kasih Manado.

3. Mengumpulkan data yang terkait dengan penelitian dari buku-buku atau literaturliteratur.

Membandingkan data yang diperoleh dari RSU Pancaran Kasih Manado berupa laporan dan hasil wawancara dengan teori dalam PSAK No.16 (Revisi 2011) yang mengatur tentang perlakuan akuntansi aset tetap

Dalam penelitian ini, teknik pengumpulan data yang digunakan adalah teknik wawancara dengan pihak terkait, dan dokumentasi berupa laporan keuangan dan daftar aset tetap yang dimiliki RSU Pancaran Kasih Manado.

Metode yang digunakan dalam menganalisis data penelitian ini adalah metode deskriptif, yaitu proses pemecahan masalah yang diselidiki dengan menjabarkan atau melukiskan kondisi objek penelitian pada periode penelitian berdasarkan fakta-fakta yang ada.

\section{HASIL ANALISIS DAN PEMBAHASAN}

\subsection{Hasil Analisis}

Kebijakan akuntansi yang berlaku di RSU Pancaran Kasih Manado merupakan dasar bagi kegiatan akuntansi keuangan. Periode akuntansi RSU Pancaran Kasih Manado dalam penyajian laporan keuangan adalah satu tahun menurut tahun takwin, yaitu 1 Januari s/d 31 Desember.

RSU Pancaran Kasih Manado merupakan salah satu penyedia sarana dan prasarana pelayanan kesehatan bagi masyarakat, yang tentunya sangat membutuhkan aset tetap dalam melaksanakan aktivitas operasional perusahaan.

Pada perusahaan ini, aset tetap diartikan sebagai aset yang dimiliki untuk digunakan dalam kegiatan operasional perusahaan, memberikan manfaat ekonomi bagi perusahaan dan dapat digunakan lebih dari satu tahun atau satu periode akuntansi.

Cara perolehan aset tetap pada RSU Pancaran Kasih Manado secara umum ada tiga jenis, yaitu perolehan dengan pembelian tunai siap pakai, dibangun sendiri (konstruksi), dan melalui donasi (sumbangan). Aset tetap meliputi aset yang dapat disusutkan (Gedung, Kendaraan, Peralatan Medis dan Non Medis) dan yang tidak dapat disusutkan (Tanah).

Kebijakan akuntansi terhadap aset tetap yang dimiliki RSU Pancaran Kasih Manado memang tidak diatur secara baku dalam sebuah buku dan tidak memiliki catatan atas laporan keuangan dari laporan audit karena hasil pemeriksaan dari yayasan belum dikembalikan ke pihak perusahaan, sehingga penyajian informasi mengenai perlakuan aset tetap masih terbatas. Perlakuan akuntansi terhadap aset tetap di RSU Pancaran Kasih Manado didasarkan pada prinsip yang diterapkan dari tahun ke tahun dan disesuaikan dengan aturan akuntansi yang berlaku secara umum. Aset tetap yang dimiliki RSU Pancaran Kasih Manado terdiri dari tanah, bangunan, peralatan medis, dan peralatan non medis. 


\subsubsection{Penggolongan Aset Tetap}

Sebagai penyedia jasa pelayanan kesehatan, RSU Pancaran Kasih Manado memiliki aset tetap dalam jumlah yang besar dan terdiri dari berbagai jenis barang, sehingga dilakukan pengelompokkan lebih lanjut atas aset-aset tetap tersebut. Daftar jenis aset tetap di RSU Pancaran Kasih Manado yang telah digolongkan dalam beberapa kelompok aset tetap, dapat dilihat pada Gambar 4.1 berikut :

Gambar 4.1 Daftar Aset Tetap di RSU Pancaran Kasih Manado

\begin{tabular}{cccc}
\hline No. & Jenis aset tetap & Masa manfaat & Harga perolehan \\
\hline 1. & Tanah & Rp. 15,243,750,000 \\
2. & Gedung dan bangunan & 25 & Rp. 5,644,076,761 \\
3. & Kendaraan & 5 & Rp. $755,000,000$ \\
4. & Peralatan non medis & 5 & Rp. 2, 159,835,434 \\
5. & 5 & Rp. 5,814,642,245 \\
& Akumulasi Penyusutan & Rp. 29,617,304,440 \\
& Jumlah Aset Tetap & (Rp. 5, 034,941,700) & Rp. 24,582,362,740 \\
\hline
\end{tabular}

Sumber : Neraca RSU Pancaran Kasih Manado, 2010

\subsubsection{Perlakuan Akuntansi terhadap Aset Tetap yang diterapkan di RSU Pancaran Kasih Manado}

Berdasarkan hasil penelitian yang diperoleh dari RSU Pancaran Kasih Manado, Perlakuan akuntansi terhadap aset tetap yang diterapkan perusahaan mulai dari pengakuan, pengeluaran setelah pengakuan, pengukuran, penyusutan, penghentian dan pelepasan serta penyajian dan pengungkapan aset tetap dalam pelaporan keuangan, bisa dilihat dari uraian berikut ini :

\section{a. Pengakuan Aset Tetap di RSU Pancaran Kasih Manado}

Berdasarkan hasil penelitian yang dilakukan pada RSU Pancaran Kasih Manado untuk perlakuan aset tetapnya diketahui bahwa pengakuan aset tetap terjadi jika kemungkinan besar aset tetap yang dimiliki memberikan manfaat ekonomi bagi entitas, maksudnya kepemilikan aset tetap memberikan manfaat ekonomi untuk menunjang kegiatan operasional perusahaan sehingga bisa memperoleh keuntungan dari penggunaan aset tetap tersebut. Biaya perolehan aset tetap harus dapat diukur secara andal, yaitu dengan menjumlahkan harga perolehan dan seluruh biaya yang terjadi hingga aset tetap tersebut siap untuk digunakan. Selain itu, aset tetap diakui ketika diperkirakan masa kegunaannya lebih dari satu periode akuntansi. Pengakuan aset tetap di RSU Pancaran Kasih Manado dicatat berdasarkan tanggal terjadinya transaksi perolehan aset tetap tersebut, berdasarkan bukti pengeluaran kas untuk pembelian atau pembiayaan aset tetap. 


\section{Biaya Perolehan Awal}

RSU Pancaran Kasih Manado menerapkan tiga cara perolehan aset tetap, yaitu dengan pembelian secara tunai, dibangun sendiri, dan melalui donasi (sumbangan).

1. Pembelian secara tunai

Pada RSU Pancaran Kasih Manado, sebelum diputuskan untuk membeli aset tetap, dibuat perencanaan pembelian aset tetap dengan tujuan yang jelas dan sesuai kebutuhan entitas.

Contohnya, perusahaan membeli satu unit mobil ambulance dengan harga $\mathrm{Rp}$. 200.000.000 secara tunai. Ayat jurnal yang perlu dibuat untuk mencatat transaksi pembelian aset tetap secara tunai adalah :

(D) Kendaraan

(K) Kas
Rp200.000.000,-

Rp. 200.000.000,-

2. Dibangun sendiri

Harga perolehan aset tetap RSU Pancaran Kasih Manado yang dibangun sendiri meliputi seluruh pengeluaran yang terjadi sehubungan dengan pembangunan aset tetap tersebut hingga siap digunakan, misalnya biaya material, biaya tenaga kerja, biaya sewa peralatan konstruksi, biaya pengurusan izin pembangunan dan lain sebagainya. Pembiayaan konstruksi awalnya dicatat sebagai Aktiva dalam penyelesaian, kemudian akan diklasifikasi menjadi akun Bangunan ketika proses konstruksi telah selesai dan bangunan siap digunakan.

Contohnya, perusahaan memutuskan untuk membangun sebuah gedung baru, yang diperkirakan membutuhkan waktu lebih dari satu periode akuntansi untuk penyelesaiannya. Ayat jurnal yang diperlukan untuk mencatat pembiayaan selama masa konstruksi adalah :

(D) Aktiva dalam penyelesaian (K) Kas
Rp. $x \times x \times x x x \times x x x,-$

Rp. $x x x x x x x x x x$,-

Ayat jurnal yang diperlukan untuk mengklasifikasi akun Aktiva dalam penyelesaian menjadi akun Bangunan adalah :

(D) Bangunan

Rp. $x x x x x x x x x x$,-

(K) Aktiva dalam penyelesaian Rp. xxxxxxxxxx,-

3. Donasi (Sumbangan)

Aset tetap RSU Pancaran Kasih Manado yang diperoleh melalui sumbangan diakui sebagai pendapatan atau keuntungan dalam periode dimana aset tetap tersebut diterima dan dicatat sebesar nilai pasar wajarnya.

Contohnya, perusahaan mendapat sumbangan dari pihak ketiga berupa 5 unit komputer untuk kebutuhan administrasi, dan nilai pasar untuk satu unit komputer seharga Rp. 5.000.000. Ayat jurnal yang dibutuhkan untuk mencatat perolehan aset tetap melalui donasi (sumbangan), adalah :

(D) Peralatan non medis (Komputer) Rp. 25.000.000,-

(K)Pendapatan

Rp. 25.000.000,-

Pada dasarnya, penentuan harga perolehan didasarkan pada harga beli di tambah semua biaya yang dikeluarkan untuk memperoleh aset tetap tersebut hingga siap digunakan.

\section{Biaya Selanjutnya}

Ada dua perlakuan untuk pengeluaran selama masa penggunaan aset tetap yang diterapkan di RSU Pancaran Kasih Manado, yaitu:

1. Pengeluaran modal (Capital expenditure)

Yang digolongkan sebagai pengeluaran modal adalah biaya yang dikeluarkan untuk memperoleh, menambah kapasitas aset tetap atau memperpanjang masa manfaat aset tetap. Pengeluaran modal tidak dibebankan langsung sebagai beban dalam laporan laba 
rugi, tapi dicatat dengan cara mendebit akun aset tetap di neraca, karena pengeluaran modal akan memberikan manfaat bagi perusahaan dimasa mendatang.

Contohnya, penambahan ruangan radiologi dan laboratorium terhadap gedung rumah sakit menghabiskan biaya sebesar Rp. 300.000.000. Ayat jurnal yang perlu dibuat untuk mencatat penambahan ini adalah :

(D) Gedung Rp. 300.000.000,-
(K) Kas
Rp. 300.000.000,-

2. Pengeluaran pendapatan (Revenue expenditure)

Yang digolongkan sebagai pengeluaran pendapatan adalah biaya yang langsung dibebankan sebagai beban dalam laporan laba rugi periode berjalan dimana biaya terjadi (dikeluarkan). Contohnya, penggantian oli mobil dinas dan mobil ambulance secara berkala, dengan biaya Rp.1.000.000. Ayat jurnal yang perlu dibuat, adalah :

(D) Biaya pemeliharaan kendaraan Rp.1.000.000,-

$$
\text { (K) Kas }
$$

\section{b. Pengukuran Aset Tetap di RSU Pancaran Kasih Manado}

$$
\text { Rp. 1.000.000,- }
$$

Berdasarkan hasil penelitian dapat diuraikan mengenai perlakuan akuntansi aset tetap pada RSU Pancaran Kasih Manado, pada kebijakan perusahaan tercantum harga perolehan aset tetap meliputi harga beli aset tetap serta biaya-biaya yang dikeluarkan sampai aset yang bersangkutan siap digunakan. Penentuan harga perolehan untuk setiap aset tetap yang dimiliki RSU Pancaran Kasih Manado baik yang dikonstruksi sendiri atau tidak, menggunakan prinsip yang sama, yaitu dengan menjumlahkan harga perolehan aset dengan seluruh biaya yang terjadi untuk memperoleh aset tetap tersebut. Pencatatan aset tetap didasarkan atas harga perolehannya masing-masing dan dikurangi dengan akumulasi penyusutan aset tetap. RSU Pancaran Kasih Manado tidak melakukan revaluasi aset tetap.

\section{c. Penyusutan Aset Tetap di RSU Pancaran Kasih Manado}

Setiap aset tetap yang dimiliki RSU Pancaran Kasih Manado dipisahkan menurut kelompok aset tetap seperti tanah, bangunan, kendaraan, peralatan medis dan non medis. Semua aset tetap yang ada (kecuali tanah), disusutkan setiap tahunnya selama umur manfaat masing-masing aset tetap. Perlakuan akuntansi untuk penyusutan aset tetap di RSU Pancaran Kasih Manado dialokasikan dengan menggunakan metode penyusutan garis lurus (Straight line method), dimana harga perolehan aset tetap dikurangi dengan taksiran nilai sisa, kemudian dibagi dengan taksiran umur ekonomis aset tetap itu sendiri. Contohnya, peralatan medis yang diperoleh dengan harga Rp. 50.000.000, masa manfaatnya selama 5 tahun, dan taksiran nilai residu sebesar Rp. 5.000.000. Besaran beban penyusutan berdasarkan metode garis lurus dihitung sebagai berikut :

$$
\begin{aligned}
& \frac{\text { Harga perolehan }- \text { estimasi nilai residu }}{\text { Estimasi umur manfaat }} \\
& =\frac{\text { Rp. } 50.000 .000-5.000 .000}{5 \text { tahun }} \\
& =\frac{\text { Rp. } 45.000 .000}{5 \text { tahun }}=\text { Rp. } 9.000 .000 / \text { tahun }
\end{aligned}
$$

Jurnal yang diperlukan untuk mencatat pembebanan penyusutan per tahun adalah sebagai berikut :

(D)Beban penyusutan

(K)Akumulasi penyusutan

Rp. 9.000.000,-

$$
\text { Rp. 9.000.000,- }
$$




\section{d. Penghapusan dan Pelepasan Aset Tetap di RSU Pancaran Kasih Manado}

Setiap aset tetap yang dimiliki RSU Pancaran Kasih Manado memiliki masa manfaat masing-masing. Ketika suatu aset tetap telah habis disusutkan atau sudah tidak bisa digunakan lagi, aset tetap tersebut akan dieliminasi pencatatannya dari pelaporan keuangan. Perlakuan untuk penghapusan dan pelepasan aset tetap di RSU Pancaran Kasih Manado adalah :

1. Pemusnahan

Aset tetap yang sudah melewati masa manfaat dan mengalami kerusakan sehingga tidak bisa digunakan lagi dalam kegiatan operasional akan dihentikan penggunaannya. Aset tetap yang akan dimusnahkan dikumpulkan kemudian dimusnahkan dengan cara dan ketentuan yang sesuai dengan kebijakan perusahaan.

2. Penghapusan

Penghapusan aset tetap perusahaan bukan karena aset tetap tersebut sudah melampaui masa manfaatnya, namun ketika perusahaan mengalami kecurian serta bencana alam yang menyebabkan perusahaan kehilangan aset tetap yang dimiliki. Pelaporan penghapusan aset tetap dilakukan paling lama 7 (tujuh) hari kerja setelah kejadian.

Ayat jurnal yang perlu dibuat untuk mencatat pelepasan aset tetap adalah sebagai berikut :

(D) Akumulasi penyusutan-kendaraan Rp. xxxxxx,-
(K) Kendaraan
Rp. $x x x x x x$,

\section{e. Penyajian dan Pengungkapan Aset Tetap dalam Laporan Keuangan}

Dalam hal penyajian dan pengungkapan aset tetap dalam pelaporan keuangan, masih banyak hal yang belum diterapkan perusahaan, terkait dengan permasalahan manajemen yang dialami beberapa tahun sebelumnya. Terkait dengan kondisi perusahaan yang baru mulai merangkak naik dan beroperasi kembali, sistem pelaporan keuangan yang diterapkan perusahaan saat ini masih bersifat pelaporan standar, sehingga terdapat banyak kekurangan dalam hal penyajian informasi khususnya mengenai aset tetap. RSU Pancaran Kasih Manado menyajikan aset tetap dalam neraca berdasarkan harga perolehannya, dan penyajian akumulasi penyusutan dimaksudkan sebagai pengurang atas aset tetap agar mudah dipahami pembaca atau pengguna laporan keuangan. Contoh penyajian jumlah tercatat aset tetap di neraca RSU Pancaran Kasih Manado dapat dilihat pada gambar 4.2 berikut :

Gambar 4.2 Penyajian jumlah tercatat aset tetap dalam neraca

\begin{tabular}{|lrr|}
\hline Tanah/hak atas tanah & Rp. 15.243.750.000 & \\
Gedung \& bangunan & Rp. 5.644 .076 .761 & \\
Kendaraan & Rp. 755.000 .000 & \\
Peralatan Non Medis & Rp. 2.159.835.434 & \\
Peralatan Medis & Rp. 5.814.642.245 & \\
Akumulasi penyusutan & & Rp. 29.617.304.440 \\
Jumlah Aset Tetap & & ( Rp. 5.034.941.700) \\
\hline
\end{tabular}

Sumber : Neraca RSU Pancaran Kasih Manado, 2010

\subsection{Pembahasan}

Data penelitian diperoleh dari pengamatan yang telah dilakukan di RSU Pancaran Kasih Manado. Penelitian dilakukan dengan teknik wawancara kepada staf keuangan dan perlengkapan serta teknik dokumentasi yaitu berupa data tertulis laporan keuangan dan daftar aset tetap. Data penelitian yang diperoleh dari perusahaan akan dibandingkan dengan ketentuan 
PSAK No.16 (revisi 2011) tentang aset tetap. Pembahasan perbandingan antara ketentuan PSAK No.16 (revisi 2011) dengan perlakuan akuntansi terhadap aset tetap yang diterapkan di RSU Pancaran Kasih Manado dapat dilihat pada tabel 4.1 sampai tabel 4.6 berikut ini.

\subsubsection{Analisis Pengakuan Aset Tetap pada RSU Pancaran Kasih Manado.}

Tabel 4.1 Perbandingan pengakuan aset tetap oleh RSU Pancaran Kasih Manado dengan PSAK No.16 (revisi 2011).

\begin{tabular}{|c|c|c|c|}
\hline PSAK Nomor 16 & $\begin{array}{c}\text { RSU Pancaran Kasih } \\
\text { Manado }\end{array}$ & Sesuai & $\begin{array}{l}\text { Tidak } \\
\text { Sesuai }\end{array}$ \\
\hline $\begin{array}{l}\text { a. Kemungkinan besar entitas } \\
\text { akan memperoleh manfaat } \\
\text { ekonomi masa depan dari } \\
\text { aset tersebut. }\end{array}$ & $\begin{array}{l}\text { Pengakuan aset tetap terjadi } \\
\text { jika kemungkinan besar aset } \\
\text { yang dimiliki memberikan } \\
\text { manfaat ekonomi bagi entitas. }\end{array}$ & $\sqrt{ }$ & \\
\hline $\begin{array}{l}\text { b. Biaya perolehan dapat } \\
\text { diukur secara andal. }\end{array}$ & $\begin{array}{l}\text { Biaya perolehan dapat diukur } \\
\text { secara andal. }\end{array}$ & $\sqrt{ }$ & \\
\hline c. & $\begin{array}{l}\text { Masa kegunaan aset tetap lebih } \\
\text { dari satu periode akuntansi }\end{array}$ & & \\
\hline
\end{tabular}

Sumber : Data Olahan, 2015

Berdasarkan tabel 4.1, dapat dilihat perbandingan antara ketentuan PSAK No.16 (revisi 2011) dan penerapan akuntansi terhadap aset tetap yang diterapkan di RSU Pancaran Kasih Manado. Sesuai dengan hasil penelitian yang ada, perlakuan akuntansi untuk pengakuan aset tetap yang diterapkan RSU Pancaran Kasih Manado telah sesuai dengan ketentuan PSAK No.16 (revisi 2011).

\subsubsection{Analisis Pengeluaran atas Aset Tetap Setelah Perolehan pada Kasih Manado}

RSU Pancaran

Tabel 4.2 Perbandingan Pengeluaran atas Aset Tetap Setelah Perolehan oleh RSU Pancaran Kasih Manado berdasarkan PSAK No. 16 (revisi 2011) 


\begin{tabular}{|c|c|c|c|}
\hline PSAK No. 16 & $\begin{array}{c}\text { RSU Pancaran Kasih } \\
\text { Manado }\end{array}$ & Sesuai & $\begin{array}{l}\text { Tidak } \\
\text { Sesuai }\end{array}$ \\
\hline $\begin{array}{l}\text { a. Pengeluaran setelah perolehan awal } \\
\text { suatu aset tetap yang meningkatkan } \\
\text { efisiensi operasional dan kapasitas } \\
\text { produktif aset tetap, serta } \\
\text { memperpanjang masa manfaat aset } \\
\text { tetap tidak dibebankan langsung } \\
\text { sebagai beban dalam laporan laba } \\
\text { rugi, melainkan dikapitalisasi } \\
\text { terlebih dahulu sebagai aset tetap di } \\
\text { neraca dan harus ditambahkan pada } \\
\text { jumlah tercatat pada aset } \\
\text { bersangkutan. }\end{array}$ & $\begin{array}{l}\text { Pengeluaran modal tidak } \\
\text { dibebankan langsung } \\
\text { sebagai beban dalam laporan } \\
\text { laba rugi, tapi dicatat dengan } \\
\text { cara mendebit akun aset } \\
\text { tetap di neraca, karena } \\
\text { pengeluaran modal akan } \\
\text { memberikan manfaat bagi } \\
\text { perusahaan dimasa } \\
\text { mendatang. }\end{array}$ & $\sqrt{ }$ & \\
\hline $\begin{array}{l}\text { b. Pengeluaran untuk perbaikan atau } \\
\text { perawatan aset tetap yang hanya } \\
\text { akan memberi manfaat dalam } \\
\text { periode berjalan, tidak akan } \\
\text { dikapitalisasi sebagai aset tetap di } \\
\text { neraca, melainkan akan langsung } \\
\text { dibebankan sebagai beban dalam } \\
\text { laporan laba rugi periode berjalan } \\
\text { dimana biaya terjadi (dikeluarkan). }\end{array}$ & $\begin{array}{l}\text { Pengeluaran pendapatan } \\
\text { adalah biaya yang langsung } \\
\text { dibebankan sebagai beban } \\
\text { dalam laporan laba rugi } \\
\text { periode berjalan dimana } \\
\text { biaya terjadi (dikeluarkan). } \\
\text { Contohnya, beban untuk } \\
\text { pemeliharaan dan perbaikan } \\
\text { aset tetap. }\end{array}$ & $\sqrt{ }$ & \\
\hline
\end{tabular}

\section{Sumber : Data Olahan, 2015}

Berdasarkan tabel 4.2, dapat dilihat perbandingan antara ketentuan PSAK No.16 (revisi 2011) dan penerapan akuntansi terhadap aset tetap yang diterapkan di RSU Pancaran Kasih Manado. Sesuai dengan hasil penelitian yang ada, perlakuan akuntansi untuk pengeluaran atas aset tetap yang diterapkan RSU Pancaran Kasih Manado telah sesuai dengan ketentuan PSAK No.16 (revisi 2011).

\subsubsection{Analisis Pengukuran Aset Tetap pada RSU Pancaran Kasih Manado}

Tabel 4.3 Perbandingan pengukuran aset tetap oleh RSU Pancaran Kasih Manado dengan PSAK No.16 (revisi 2011) 
a. Aset tetap yang memenuhi Pengukuran harga perolehan aset syarat pengakuan sebagai aset tetap dihitung berdasarkan harga diukur pada biaya perolehan, beli dan ditambahkan dengan termasuk biaya impor dan pajak seluruh biaya-biaya yang terjadi pembelian yang tidak dapat hingga aset tersebut siap untuk dikreditkan setelah dikurangi digunakan. diskon pembelian dan potongan lain.

b. Biaya perolehan suatu aset tetap yang dikonstruksi sendiri ditentukan dengan menggunakan prinsip yang sama sebagaimana aset yang diperoleh bukan dengan konstruksi sendiri.

Penentuan harga perolehan untuk setiap aset tetap yang dimiliki RSU Pancaran Kasih Manado baik yang dikonstruksi sendiri atau tidak, menggunakan prinsip yang sama. Harga perolehan ditambah seluruh biaya yang terjadi saat perolehan hingga aset tetap tersebut siap digunakan.

c. Pada model biaya, setelah pengakuan aset, aset tetap dicatat pada biaya perolehan dikurangi akumulasi penyusutan dan akumulasi penurunan nilai.

d. Pada model revaluasi, setelah pengakuan sebagai aset, aset tetap yang nilai wajarnya dapat diukur secara andal dicatat pada jumlah revaluasian, yaitu nilai wajar pada tanggal revaluasi dikurangi akumulasi penyusutan dan akumulasi rugi penurunan nilai setelah tanggal revaluasi.

Sumber : Data Olahan, 2015

Berdasarkan tabel 4.3, dapat dilihat perbandingan antara ketentuan PSAK No.16 (revisi 2011) dan penerapan akuntansi terhadap aset tetap yang diterapkan di RSU Pancaran Kasih Manado. Sesuai dengan hasil penelitian yang ada, perlakuan akuntansi untuk pengukuran aset tetap yang diterapkan RSU Pancaran Kasih Manado belum sesuai dengan ketentuan PSAK No.16 (revisi 2011), karena perusahaan tidak melakukan revaluasi aset tetap. 


\subsubsection{Analisis Penyusutan Aset Tetap pada RSU Pancaran Kasih Manado}

Tabel 4.4 Perbandingan penyusutan aset tetap oleh RSU Pancaran Kasih Manado berdasarkan ketentuan PSAK No.16 (revisi 2011)

\begin{tabular}{|c|c|c|}
\hline PSAK No. 16 & RSU Pancaran Kasih Manado & Sesuai \\
\hline $\begin{array}{l}\text { a. Setiap bagian dari aset tetap yang } \\
\text { memiliki biaya perolehan cukup } \\
\text { signifikan terhadap total biaya } \\
\text { perolehan seluruh aset harus } \\
\text { disusutkan secara terpisah. }\end{array}$ & $\begin{array}{l}\text { Setiap aset tetap disusutkan } \\
\text { secara terpisah menurut } \\
\text { pengelompokan aset tetap } \\
\text { seperti gedung, kendaraan, } \\
\text { peralatan medis dan peralatan } \\
\text { non medis. }\end{array}$ & $\sqrt{ }$ \\
\hline $\begin{array}{l}\text { b. Jumlah tersusutkan dari suatu aset } \\
\text { dialokasikan secara sistematis } \\
\text { sepanjang masa manfaatnya. }\end{array}$ & $\begin{array}{l}\text { Penyusutan aset tetap dilakukan } \\
\text { berdasarkan masa manfaat aset } \\
\text { tetap. }\end{array}$ & $\sqrt{ }$ \\
\hline $\begin{array}{l}\text { c. metode penyusutan yang dapat } \\
\text { digunakan untuk mengalokasikan } \\
\text { jumlah yang disusutkan secara } \\
\text { sistematis dari suatu aset selama } \\
\text { umur manfaatnya antara lain, } \\
\text { metode garis lurus, metode saldo } \\
\text { menurun, metode jumlah unit. }\end{array}$ & $\begin{array}{l}\text { Penyusutan aset tetap dihitung } \\
\text { menggunakan metode garis } \\
\text { lurus selama masa manfaat aset } \\
\text { tetap. }\end{array}$ & $\sqrt{ }$ \\
\hline
\end{tabular}

Sumber : Olahan, 2015

Berdasarkan tabel 4.4, dapat dilihat perbandingan antara ketentuan PSAK No.16 (revisi 2011) dan penerapan akuntansi terhadap aset tetap yang diterapkan di RSU Pancaran Kasih Manado. Sesuai dengan hasil penelitian yang ada, perlakuan akuntansi untuk penyusutan aset tetap yang diterapkan RSU Pancaran Kasih Manado telah sesuai dengan ketentuan PSAK No.16 (revisi 2011).

\subsubsection{Analisis Penghentian dan Pelepasan Aset Tetap pada RSU Pancaran Kasih Manado}

Tabel 4.5 Perbandingan perlakuan penghentian dan pelepasan aset tetap oleh RSU Pancaran Kasih Manado berdasarkan PSAK No.16 (revisi 2011)

\begin{tabular}{|c|c|c|c|}
\hline PSAK No. 16 & RSU Pancaran Kasih Manado & Sesuai & $\begin{array}{l}\text { Tidak } \\
\text { Sesuai }\end{array}$ \\
\hline $\begin{array}{l}\text { a. Jumlah tercatat aset tetap dihentikan } \\
\text { pengakuannya pada saat dilepas atau } \\
\text { ketika tidak terdapat lagi manfaat } \\
\text { ekonomi masa depan yang diharapkan } \\
\text { dari penggunaan atau pelepasannya. } \\
\text { b. Pelepasan aset tetap dapat dilakukan } \\
\text { dengan berbagai cara (misalnya: dijual, } \\
\text { disewakan berdasarkan sewa } \\
\text { pembiayaan, atau disumbangkan). }\end{array}$ & $\begin{array}{l}\text { Aset tetap yang tidak lagi } \\
\text { memberikan manfaat ekonomi } \\
\text { yang diharapkan perusahaan } \\
\text { dieliminasi dari perkiraan aset } \\
\text { tetap di neraca. } \\
\text { Untuk penghentian dan pelepasan } \\
\text { aset, perusahaan menerapkan dua } \\
\text { metode yaitu pemusnahan untuk } \\
\text { aset tetap yang sudah tidak bisa } \\
\text { digunakan lagi dan penghapusan } \\
\text { untuk aset tetap yang mengalami } \\
\text { bencana alam, atau dicuri. }\end{array}$ & $\sqrt{ }$ & \\
\hline
\end{tabular}

Sumber : Olahan, 2015 
Berdasarkan tabel 4.5, dapat dilihat perbandingan antara ketentuan PSAK No.16 (revisi 2011) dan penerapan akuntansi terhadap aset tetap yang diterapkan di RSU Pancaran Kasih Manado. Sesuai dengan hasil penelitian yang ada, perlakuan akuntansi untuk penghentian dan pelepasan aset tetap yang diterapkan RSU Pancaran Kasih Manado telah sesuai dengan ketentuan PSAK No.16 (revisi 2011).

\subsubsection{Analisis Penyajian dan Pengungkapan Aset Tetap pada RSU Pancaran Kasih Manado}

Tabel 4.6 Perbandingan penyajian dan pengungkapan aset tetap oleh RSU Pancaran Kasih Manado berdasarkan PSAK No.16 (revisi 2011)

\begin{tabular}{|c|c|c|c|}
\hline PSAK No. 16 & RSU Pancaran Kasih Manado & Sesuai & $\begin{array}{c}\text { Tidak } \\
\text { Sesuai }\end{array}$ \\
\hline $\begin{array}{l}\text { a. Aset Tetap disajikan dalam neraca } \\
\text { sebesar nilai perolehan aset tersebut } \\
\text { dikurangi } \\
\text { penyusutannya. }\end{array}$ & $\begin{array}{l}\text { Penyajian Aset Tetap dalam neraca } \\
\text { dinyatakan sebesar nilai buku, yaitu } \\
\text { harga perolehan dikurangi akumulasi } \\
\text { penyusutan, karenanya akumulasi } \\
\text { penyusutan aset tetap disajikan sebagai } \\
\text { perkiraan pengurang atas aset tetap. }\end{array}$ & $\sqrt{ }$ & \\
\hline $\begin{array}{l}\text { b. setiap jenis aset seperti tanah, bangunan, } \\
\text { inventaris kantor dan lain sebagainya } \\
\text { harus dinyatakan dalam neraca secara } \\
\text { terpisah atau terperinci dalam catatan atas } \\
\text { laporan keuangan. }\end{array}$ & $\begin{array}{l}\text { Setiap jenis aset tetap dinyatakan secara } \\
\text { terpisah berdasarkan kelompok dalam } \\
\text { neraca. Perusahaan belum menerapkan } \\
\text { pelaporan secara terperinci mengenai aset } \\
\text { tetap dalam catatan atas laporan } \\
\text { keuangan. }\end{array}$ & & $\sqrt{ }$ \\
\hline $\begin{array}{l}\text { c. dasar pengukuran yang digunakan } \\
\text { dalam menentukan jumlah tercatat bruto } \\
\text { harus diungkapkan. }\end{array}$ & $\begin{array}{l}\text { perusahaan tidak mengungkapkan dasar } \\
\text { penilaian yang digunakan untuk } \\
\text { menentukan jumlah tercatat bruto. }\end{array}$ & & $\sqrt{ }$ \\
\hline $\begin{array}{l}\text { d. Mengungkapkan metode penyusutan } \\
\text { yang digunakan, seperti metode garis } \\
\text { lurus, metode saldo menurun ganda, dan } \\
\text { metode jumlah unit. }\end{array}$ & $\begin{array}{l}\text { Untuk menentukan besaran beban } \\
\text { penyusutan, perusahaan menerapkan } \\
\text { metode garis lurus. }\end{array}$ & $\sqrt{ }$ & \\
\hline $\begin{array}{l}\text { e. umur manfaat atau tarif penyusutan } \\
\text { yang digunakan harus diungkapkan. }\end{array}$ & $\begin{array}{l}\text { perusahaan tidak mengungkapkan } \\
\text { tentang umur manfaat aset tetap. }\end{array}$ & & $\sqrt{ }$ \\
\hline $\begin{array}{l}\text { f. Jumlah tercatat bruto dan akumulasi } \\
\text { penyusutan (agregat dengan akumulasi } \\
\text { rugi penurunan nilai) diungkapkan pada } \\
\text { awal dan akhir periode }\end{array}$ & $\begin{array}{l}\text { Perhitungan dilakukan setiap akhir tahun } \\
\text { (periode) dan disajikan dalam neraca } \\
\text { pada awal periode selanjutnya. }\end{array}$ & $\sqrt{ }$ & \\
\hline $\begin{array}{l}\text { Laporan keuangan juga harus mengungl } \\
\text { a. Keberadaan dan jumlah pembatasan atas } \\
\text { hak milik dan aset tetap yang dijaminkan } \\
\text { untuk liabilitas }\end{array}$ & $\begin{array}{l}\text { xapkan: } \\
\text { Perusahaan tidak mengungkapkan } \\
\text { mengenai keberadaan dan jumlah } \\
\text { pembatasan atas hak milik dan aset tetap } \\
\text { yang dijaminkan dalam pelaporan } \\
\text { keuangan. }\end{array}$ & & $\sqrt{ }$ \\
\hline $\begin{array}{l}\text { b. Jumlah pengeluaran diakui dalam } \\
\text { jumlah tercatat aset tetap yang sedang } \\
\text { dalam konstruksi }\end{array}$ & $\begin{array}{l}\text { Pengeluaran untuk aset tetap yang sedang } \\
\text { dalam proses pembangunan diakui dalam } \\
\text { jumlah tercatat aset tetap (aktiva dalam } \\
\text { penyelesaian). }\end{array}$ & $\sqrt{ }$ & \\
\hline $\begin{array}{l}\text { c. Jumlah komitmen kontraktual dalam } \\
\text { perolehan aset tetap. }\end{array}$ & $\begin{array}{l}\text { Jumlah komitmen kontraktual dalam } \\
\text { perolehan aset tetap tidak disajikan. }\end{array}$ & & $\sqrt{ }$ \\
\hline
\end{tabular}

Sumber : Olahan, 2015 
Berdasarkan tabel 4.6, dapat dilihat perbandingan antara ketentuan PSAK No.16 (revisi 2011) dan penerapan akuntansi terhadap aset tetap yang diterapkan di RSU Pancaran Kasih Manado. Sesuai dengan hasil penelitian yang ada, perlakuan akuntansi untuk penyajian dan pengungkapan aset tetap yang diterapkan RSU Pancaran Kasih Manado belum sesuai dengan ketentuan PSAK No.16 (revisi 2011), karena masih banyak informasi tentang aset tetap yang belum disajikan dan diungkapkan dalam catatan atas laporan keuangan perusahaan, seperti pemisahan aset tetap, dasar penilaian untuk menentukan jumlah tercatat bruto, umur manfaat masing-masing aset tetap, keberadaan dan jumlah pembatasan atas hak milik serta aset tetap yang dijaminkan, jumlah komitmen kontraktual dalam perolehan aset tetap juga tidak diungkapkan.

\section{KESIMPULAN}

Berdasarkan teori mengenai aset tetap dan melakukan analisa mengenai penerapan akuntansi aset tetap berdasarkan Pernyataan Standar Akuntansi Keuangan No. 16 (revisi 2011) pada RSU Pancaran Kasih Manado maka dapat disimpulkan

1. Perlakuan akuntansi untuk pengakuan aset tetap yang diterapkan RSU Pancaran Kasih Manado telah sesuai dengan ketentuan yang tercantum dalam PSAK No.16 (revisi 2011).

2. Perlakuan akuntansi untuk pengeluaran atas aset tetap yang diterapkan oleh RSU Pancaran Kasih Manado telah sesuai dengan PSAK No.16 (revisi 2011).

3. Perlakuan akuntansi untuk pengukuran atas aset tetap yang diterapkan RSU Pancaran Kasih Manado belum sesuai dengan ketentuan yang tercantum dalam PSAK No.16 (revisi 2011).

4. Perlakuan akuntansi untuk penyusutan aset tetap yang diterapkan RSU Pancaran Kasih Manado telah sesuai dengan ketentuan yang tercantum dalam PSAK No.16 (Revisi 2011).

5. Perlakuan akuntansi untuk penghentian dan pelepasan aset tetap yang diterapkan RSU Pancaran Kasih Manado telah sesuai dengan ketentuan yang tercantum dalam PSAK No.16 (Revisi 2011).

6. Perlakuan akuntansi untuk penyajian dan pengungkapan aset tetap yang diterapkan RSU Pancaran Kasih Manado belum sesuai dengan ketentuan yang tercantum dalam PSAK No.16 (Revisi 2011).

Adapun saran yang bisa diajukan adalah

1. Perlakuan akuntansi untuk pelepasan dan penghentian pengakuan aset tetap tidak hanya diterapkan bagi aset tetap yang sudah habis disusutkan. Untuk aset tetap yang mengalami kejadian tidak biasa seperti bencana alam atau hilang tentu masih memiliki nilai yang belum habis disusutkan. Entitas seharusnya mencatat keuntungan atau kerugian dari pelepasan aset tetap tersebut.

2. Secara umum penyajian dan pengungkapan aset tetap dalam penerapannya sudah baik. Namun, agar laporan keuangan lebih informatif sebaiknya perusahaan menambahkan informasi seperti dasar pengukuran yang digunakan dalam menentukan jumlah tercatat bruto, umur manfaat aset tetap, keberadaan dan jumlah pembatasan atas hak milik dan aset tetap yang dijaminkan, serta jumlah komitmen kontraktual dalam perolehan aset tetap tidak disajikan, sehingga lebih muda dimengerti oleh pemakai laporan keuangan.

\section{DAFTAR PUSTAKA}

Hermika, Dona Fira. 2009. Analisis perlakuan akuntansi terhadap aset tetap berwujud pada PT. Pandu Siwi Sentosa Palembang (PSAK No.16 tahun 1994 ke konvergensi IFRS. http://eprints.mdp.ac.id/944/\&sa. Diakses:Juni,14,2015. 
Hery. 2011. Akuntansi Aktiva, Hutang, dan Modal. Edisi pertama. Penerbit Gava Media. Yogyakarta.

Hery. 2012. Cara Mudah Memahami Akuntansi : Inti Sari Konsep Dasar Akuntansi. Penerbit Prenada Media Group. Jakarta.

Hery. 2013. Akuntansi Dasar 1 \& 2. Penerbit PT Grasindo. Jakarta.

Ikatan Akuntan Indonesia (IAI). 2011. Standar Akuntansi Keuangan. Penerbit Graha Akuntan, Jakarta.

Juan, Ng Eng \& Wahyuni, Ersa Tri. 2012. Panduan praktis Standar Akuntansi Keuangan. Edisi kedua. Penerbit Salemba Empat, Jakarta.

Libby.R, Libby.P.A, Short.D.G. 2008.Akuntansi Keuangan. Edisi kelima. Penerbit Andi. Yogyakarta.

Mukhtar. 2013. Metode Praktis Penelitian Deskriptif Kualitatif. Penerbit Referensi. Jakarta.

Pany, Nadia Fedora Devina Dae. 2015. Analisis Penerapan PSAK NO.16 (Revisi 2011) tentang Aset Tetap (Studi Kasus : RSU Wiradadi Husada). http://etd.repository.ugm.ac.id/index.php. Diakses : Juni, 14, 2015.

Pontoh, Winston. 2013. Akuntansi Konsep dan Aplikasi. Penerbit Halaman Moeka Publishing. Jakarta.

Putra, Trio Mandala. 2013. Analisis Penerapan Akuntansi Aset Tetap pada $\quad C v$. Kombos Manado. 1(3), 1646-3028.

Revee.J.M, Warren.C.S, Duchac.J.E, Wahyuni.E.T, Soepriyanto.G, Jusuf.A.A, Djakman.Ch.D. 2010. Pengantar Akuntansi adaptasi Indonesia Jilid 2. Penerbit Salemba Empat, Jakarta.

Riahi,Ahmed \& Belkaoui. 2011. Accounting Theory. Buku satu. Edisi 5. Penerbit Salemba Empat. Jakarta.

Santoso, Iman. 2007. Akuntansi Keuangan Menengah (Intermediate Accounting). Penerbit PT Refika Aditama. Bandung.

Sugiyono. 2012. Metode Penelitian Pendidikan : Pendekatan Kuantitatif, Kualitatif, dan $R$ \& $D$. Penerbit Alfabeta. Bandung. 